【論文】

\title{
自由車・追従車構成に着目した車頭時間 分布モデルに関する研究
}

\author{
TIME HEADWAY DISTRIBUTION MODEL BASED ON THE COMPOSITION \\ OF FREE AND CONSTRAINED FLOWING VEHICLES
}

\author{
田 村 洋 一*・㯪 木 武** \\ By Youichi TAMURA and Takeshi CHISHAKI
}

\section{1. まえがき}

交通流の効果的管理を図る諸施策を検討するために, 交通流現象の正確な把握が必要であることはいうまでも ない. 特に最近のように, 全市民的に自動車が普及した にもかかわらず，道路施設整備が追いつけない状態で は, 交通の安全性や施設の有効利用を当面の策として論 議することになるが，その前提として交通流の諸現象を 精度よく解明し, 有用な諸情報を提供することが一段と 望まれるであろう。

交通流の基本は, 自由あるいは追従的に走行する個々 の車の集合体である. したがって，この意味で確率論的 にアプローチ寸る試みは交通現象把握の観点から本質的 なものであるといえ, その面からの研究も多々ある. そ の際, 交通流現象をどのような物理量でとらえ, 正確に 表現するかが常に問題になる. 寸なわち, 交通流の物理 量として, 速度, 密度, 交通量, 占有率などがあるが, これらのうちで交通流の内部構造に立ち入った根元的検 討が可能であること, 測定が直接的で容易であることな どを踏まえると, 車頭間隔と交通量とが交通流記述の重 要な基本量になると判断される.

本研究は, 上述の認識に立ち, 交通流の内部構造を分 析する過程から, 車頭時間の確率分布について検討し, そのモデルを提案するものである. 周知のように, 車頭 間隔分布は, 従来から多くの研究がなされているが1) 9), それらのなかで, 交通流を自由車, 追従車の 2 面構成で とらえ, それぞれ異なる分布を仮定したいわゆる複合分

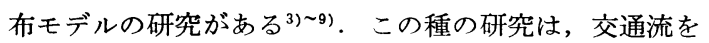
その内部構造と関連して把握するうえで望ましい一法で あり, その最初のものは, A. Schuhl ${ }^{3)}$ による複合指数 分布モデルの適用であろら. 以来, 指数分布, ガンマ分

* 正会員 工修 山口大学助手 建設工学科

** 正会員 工博 九州大学教授 士木工学科
布, アーラン分布, 対数正規分布, 正規分布などの組合せ に基づく複合分布モデルの適用が検討されている(4) . しかし,これら従来の研究に㧍ける基本的問題点として 次のことが指摘できる. 寸なわち, 従来の研究は交通流 の自由車, 追従車構成を単に複合分布モデル適用上の概 念として用いたにすぎず，両者の定義は明確でなく，ま た, 具体的なモデルの評価を観測分布の総括的取扱いに より把握しているにすぎない. このため, 得られた分布 モデルは計算に用いられた観測データの良好な再現性を 与えるにしても, 交通流の内部構造把握に值接寄与する ものでない，換言すれば, 従来の研究成果である諸分布 モデルは, 観測データの表現を主たる目的に構築された ものであり, また, 交通流記述のも51つの基本量であ る速度分布と直接関係づけられていないことにも起因し て, 個々の交通状態の表面的な再現性を与えるにすぎ ず, 非渋滞流から渋滞流に至る諸交通状態の変化に対応 する一貫した汎用性, 交通流の内部構造解明という点で 大いに疑問が残る. そこで, 本研究は, 交通流が自由車 と追従車とから構成されることを前提に, その内部構造 が把握できること, 現象に対する適合性が高いこと, 交 通状態の広範な変化に即応する汎用性があることを意図 して, 新たな車頭時間分布モデルの構築を図るものであ る. 具体的には, 非渋滞流から渋滞流に至る交通流を対 象に,

(1) 自由車, 追従車の定義と分離方法

(2) 自由車, 追従車の分離に基づく車頭時間分布モデ ルの構築

(3) モデルのパラメーターと交通量との関係 の 3 観点を中心に検討するものである.

本研究で用いた観測データは, 国道 2 号線（小郡バイ パス, 牟礼江泊), 190 号線 (柳ケ瀬, 恩田, 後潟), 202 号線 (福吉) の平坦で直線的な郊外部 2 車線追越禁止区 間で観測されたものであり, 表一1 にその概要を示す. 国道 202 号線での観測には $16 \mathrm{~mm}$ メモモーションカメ 
表一1 観測日時, 対象区間およびデータ規模

\begin{tabular}{|c|c|c|}
\hline Date and Duration & Location & $\begin{array}{c}\text { No. of Observed } \\
\text { Vehicles }\end{array}$ \\
\hline $\begin{array}{l}\text { 22th. Sept. } 1977 \\
\text { p.m. } 1: 55 \sim 3: 00\end{array}$ & Yanagase (Route 190) & 459 \\
\hline $\begin{array}{l}\text { 22th. Sept. } 1977 \\
\text { p.m. } \quad 4: 52 \sim 6: 05\end{array}$ & $"$ & 1010 \\
\hline $\begin{array}{l}\text { 28th. Oct. } 1977 \\
\text { a.m. } 7: 03 \sim 8: 30\end{array}$ & $"$ & 1201 \\
\hline $\begin{array}{l}\text { 27th. Sept. } 1977 \\
\text { p.m. } 3: 45 \sim 4: 25\end{array}$ & Ogori By-pass (Route 2) & 306 \\
\hline $\begin{array}{l}\text { 27th. Sept. } 1977 \\
\text { p.m. } \quad 4: 37 \sim 5: 50\end{array}$ & $"$ & 718 \\
\hline $\begin{array}{l}\text { 21th. Oct. } 1977 \\
\text { a.m. } 11: 00 \sim 12: 00\end{array}$ & Mureedomari (Route 2) & 907 \\
\hline $\begin{array}{l}\text { 27th. Oct. } 1977 \\
\text { a.m. } 10: 43 \sim 12: 00\end{array}$ & $"$ & 701 \\
\hline $\begin{array}{l}\text { 28th. Oct. } 1977 \\
\text { p.m. } 3: 51 \sim 4: 40\end{array}$ & Onda (Route 190) & 517 \\
\hline $\begin{array}{l}\text { 11th. Nov. } 1977 \\
\text { p.m. } 3: 50 \sim 5: 35\end{array}$ & $"$ & 1336 \\
\hline $\begin{array}{l}\text { 18th. Nov. } 1978 \\
\text { p.m. } 2: 25 \sim 3: 25\end{array}$ & Ushirogata (Route 190) & 416 \\
\hline $\begin{array}{l}\text { 18th. Nov. } 1978 \\
\text { p.m. } 3: 30 \sim 5: 00\end{array}$ & $"$ & 1353 \\
\hline $\begin{array}{l}\text { 21th. Nov. } 1978 \\
\text { a.m. } 10: 20 \sim 12: 05\end{array}$ & $"$ & 1004 \\
\hline $\begin{array}{l}\text { 21th. Nov. } 1978 \\
\text { p.m. } 12: 40 \sim 1: 46\end{array}$ & " & 615 \\
\hline $\begin{array}{l}\text { 21 th. Nov. } 1978 \\
\text { p.m. } 2: 04 \sim 4: 06\end{array}$ & 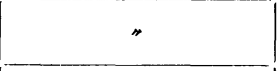 & 1114 \\
\hline $\begin{array}{l}\text { 9th. Aug. } 1981 \\
\text { p.m. } 3: 30 \sim 5: 45\end{array}$ & Fukuyoshi (Route 202) & 1845 \\
\hline
\end{tabular}

ラを用い，他の 2 路線での観測には，道路上 2 つの測定 点への車の到着時刻をストップウォッチと $8 \mathrm{~mm}$ カメラ の併用により記録し, 解析に必要な諸量を求めたもので ある. 各地点での一連のデータは， 1 分間ごとに集計し 計算に用いている。 なお， 1 分間データとしたことは, より安定した車頭時間分布モデルの作成を意図したこと と, 事後の研究になるが，交通量変動の諸分布に対し普 遍的応用性をもたせることを配虑したことによる。

\section{2. 自由車・追従車の定義と分離法}

\section{（1）自由車・追従車の定義}

交通流の内部構造の解明で問題となるのは, 自由車・ 追従車の定義である. 従来の研究では, 前章に指摘する ように, 自由車, 追従車は車頭間隔分布モデルあてはめ の結果として全交通流中に占めるそれぞれの割合を推定 し分離するか ${ }^{3) ~ 9)}$, 支るいは, 車群台数分布の研究 ${ }^{10) ~ 13)}$ にみられるように，限界車頭間隔の設定により分離する 方法が用いられている。しかしながら，いずれも自由 車, 追従車の定義が曖昧であり,このことは, 自由車, 追従車の定義が速度との関係で明確になされていないこ
とに起因するものである。

本研究では, 先行車の影響を受け, その希望速度以下 の速度で走行することを強制されている車を追従車，希 望速度を維持して走行している車を自由車と定義する. 換言すれば，ある車が自由車であるか追従車であるか は，その車が希望速度より速度低下を生じているか否か により決定され，表面的に追従走行しているように見え ても，先行車の速度に等しいか，あるいはそれ以下の希 望速度をもつ車は自由車である，したがって，ある車頭 間隔が与えられるとき，その車頭間隔で走行している車. の集合は，自由車と追従車で構成されることになる．こ のとき，自由車と追従車とを分離する問題は，それぞれ の車頭間隔で走行する車の中で自由車，追従車の割合を 推定する問題に帰着する. しかし, 現実の交通流で個々 の車の希望速度を直接知り，自由車，追従車を分離する ことはできないので, 結局, 交通挙動の表面に現われる 自由車, 追従車構成を反映する物理量を指標として, そ の構成割合を推定する方法を見出すことが現実的であ る．すなわち，連続する 2 台の車の相対速度分布と車頭 間隔との関係に着目し，自由車率 (追従車率) の概念を 導入することにより交通流の自由車・追従車構成を推定 的に求める方法がそれである.

\section{（2）相対速度分布と車頭時間との関係}

連続する 2 台の車の速度をそれぞれ $X, Y$ とし，これ らが正規分布に従らとき, 両者の相対速度 $Z=X-Y$ の 分布もまた正規分布となる. その平均 $\mu_{z}$, 分散 $\sigma_{z}{ }^{2}$ が 次の諸式で与えられることは周知の事実である.

$$
\begin{aligned}
& \mu_{z}=\mu_{x}-\mu_{y} \ldots \ldots \ldots \ldots \ldots \ldots \ldots \ldots \ldots \ldots \ldots \ldots \ldots \ldots \ldots \ldots \ldots \ldots \ldots \ldots \\
& \sigma_{z}{ }^{2}=\sigma_{x}{ }^{2}-2 \operatorname{Cov}_{x y}+\sigma_{y}{ }^{2}=\sigma_{x}{ }^{2}-2 \rho \sigma_{x} \sigma_{y}+\sigma_{y}{ }^{2}
\end{aligned}
$$

ここに, $\mu_{x}, \mu_{y}: X, Y$ の平均, $\sigma_{x}^{2}, \sigma_{y}{ }^{2}: X, Y$ の分散, $\operatorname{Cov}_{x y}: X$ と $Y$ との共分散, $\rho=\operatorname{Cov}_{x y} / \sigma_{x} \sigma_{y}$ また上述の諸関係は， $X, Y$ の分布が正規分布以外の場 合でも近似的に成立する. したがって, 相対速度の分布 は先行車, 後続車の速度分布, および, それらの相関関 係を知ることにより求めることができる.

そこで，速度分布に関するこれらのパラメーターと車 頭時間との関係を知るために, 観測データを車頭時間 1 秒ごとにクラス分けし, 対応する速度分布のパラメータ 一を計算した，その結果は図一1〜図一4である。また， 相対速度の観測データより計算された分散と車頭時間と の関係を図一5に示す. 図一1 より， $\mu_{x}, \mu_{y}$ はほぼ等し い值をとりながら，車頭時間が大きくなるにつれ，非橴 滞流ではわずかずつ増大し，橴滞流では大きく減少する ことが理解できる. 図一2より, $\sigma_{x}, \sigma_{y}$ は非渋滞流, 橴 滞流のいずれにおいても車頭時間に関し変化せず一定で 
あり，両者の值はそれほど大きな差違はない. $\operatorname{Cov}_{x y}$ は 非渋滞流において車頭時間の増加に伴い減少し, 渋滞流 において車頭時間に関し一定である. 図一4の $\rho$ もま た同様である.ここで, ある車が泾滞, 非渋滞のいずれ に属するかの判定は, 文献 14) の研究成果を踏まえて, 時速 $35 \mathrm{~km}$ を境界としてそれ以下の速度の車を渋滞車, それ以上の速度の車を非渋滞車として分類した. この速 度境界值は必ずしも絶対的なものでなく不確定な面もあ るが，このような境界設定によるパラメーターの推定精 度はそれほど敏感に影響を受けるものでないことを確認 している.

以上から, 非渋滞流に関しては, $\mu_{x}=\mu_{y}=\mu_{f}, \sigma_{x}=\sigma_{y}$ $=\sigma_{f}$ とみなすことができ，また， $\operatorname{Cov}_{x y}, \rho$ は車頭時間 の関数, すなわち, $\operatorname{Cov}_{x y}=\operatorname{Cov}_{f}(t), \rho=\rho_{f}(t)$ とする ことができる，そこで，これらを式 (1)，(2) に適用寸 ると相対速度分布の平均は零となり, 分散は車頭時間 $t$ の関数となるから, これを $\sigma_{z}{ }^{2}=\sigma_{z f^{2}}{ }^{2}(t)$ とすると

$$
\sigma_{z f^{2}}(t)=2\left\{\sigma_{f}^{2}-\operatorname{Cov}_{f}(t)\right\}=2 \sigma_{f}^{2}\left\{1-\rho_{f}(t)\right\}
$$

ここに,

$$
\rho_{f}(t)=\operatorname{Cov}_{f}(t) / \sigma_{f}^{2}
$$

$\operatorname{Cov}_{f}(t), \rho_{f}(t)$ はデー夕上りみていずれも $\ell$ の減少関 数となるので, $\sigma_{z f^{2}}{ }^{2}(t)$ はの増加関数となる。ここ

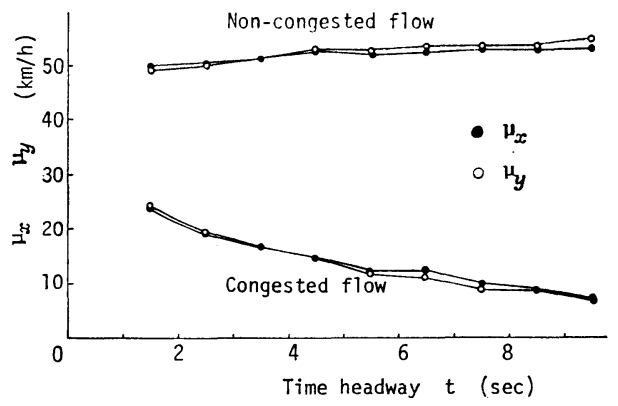

図一1 $\boldsymbol{\mu}_{x}, \boldsymbol{\mu}_{y}$ と車頭時間との関係

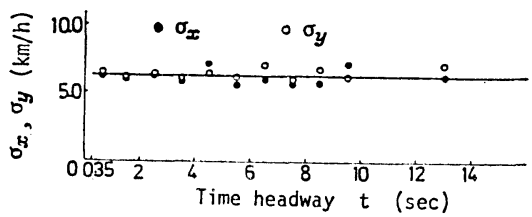

(a) Non-congested flow

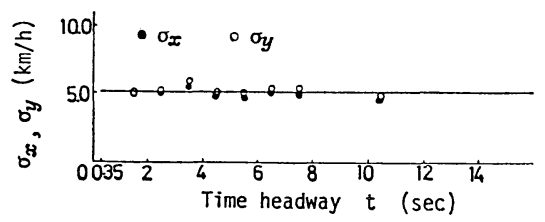

(b) Congested flow
で, 最小車頭時間を $t_{0}$ とすると, $t=t_{0}$ のとき, $\operatorname{Cov}_{f}$ $(t), \rho_{f}(t)$ はそれぞれ最大值 $\operatorname{Cov}_{f \text { max }}, \rho_{f \text { max }}$ をとり， $t \rightarrow \infty$ のときいずれも零となるから， したがって $\sigma_{z} f^{2}$ ( $t$ ) は $t=t_{0}, t \rightarrow \infty$ でそれぞれ最小值, 最大值をとる. そこで, $\sigma_{z f^{2}}(t)$ の最大值を $\sigma_{z f^{2} \mathrm{max}}$, 最小值を $\sigma_{z} f^{2}$ min とすれば

$$
\begin{aligned}
& \sigma_{z f_{\text {max }}^{2}}=2 \sigma_{f}{ }^{2} \cdots \ldots \ldots \ldots \ldots \ldots \ldots \ldots \ldots \ldots \ldots \ldots \ldots \ldots \ldots \ldots \ldots \\
& \sigma_{z f_{\text {min }}}=2\left(\sigma_{f}{ }^{2}-\operatorname{Cov}_{f \text { max }}\right)=2 \sigma_{f}^{2}\left(1-\rho_{f \text { max }}\right)
\end{aligned}
$$

したがって, $\operatorname{Cov}_{f}(t)$ を定式化することにより， $\sigma_{z} f^{2}(t)$ が定式化できる. そこで，図一3 (a) のデータに対して 曲線のあてはめを行えば, $\operatorname{Cov}_{f}(t)$ として式 (7) が得ら れた.

$$
\operatorname{Cov}_{f}(t)=\frac{B}{A\left(t-t_{0}\right)^{2}+1}
$$

ここに, $t$ : 車頭時間 $(\mathrm{s}), t_{0}=0.35(\mathrm{~s}), A=0.055\left(\mathrm{~s}^{-2}\right)$,

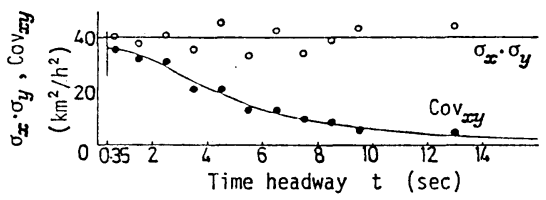

(a) Non-conqested flow

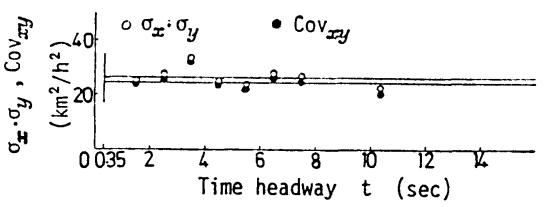

(b) Congested flow

図一3 $\sigma_{x} \cdot \sigma_{y}, \operatorname{Cov}_{x y}$ と車頭時間との関係

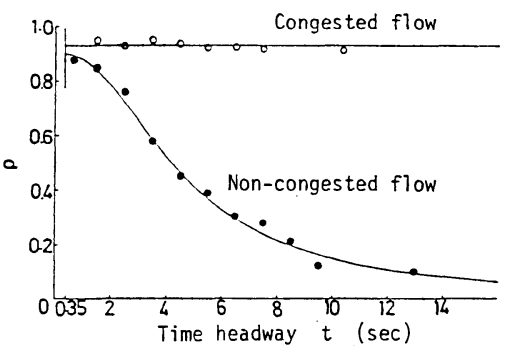

図-4 $\rho$ と車頭時間との関係

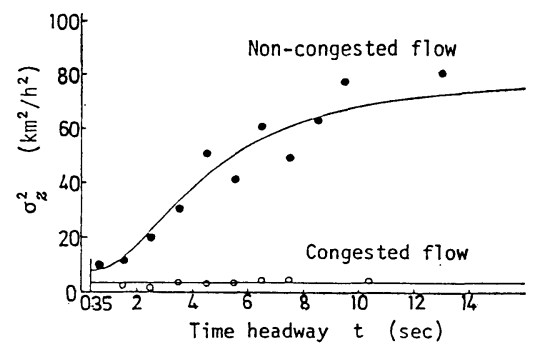

图一5 $\quad \sigma_{z}^{2}$ と車頭時間との関係 
$B=36.00\left(\mathrm{~km}^{2} / \mathrm{h}^{2}\right)$. なお， $t_{0}=0.35(\mathrm{~s})$ は観測デー夕の 最小值を採用した. 式 (7) を式 (4) に代入すれば $\rho_{f}(t)$ が求められ, 式 (3) に代入すれば $\sigma_{z} f^{2}(t)$ が求められ る.

一方, 渋滞流では, 非渋滞流と同様に, $\mu_{x}=\mu_{y}=\mu_{c}$, $\sigma_{x}=\sigma_{y}=\sigma_{c}$ とおくことができ，また $\operatorname{Cov}_{x y}=\operatorname{Cov}_{c}, \rho=$ $\rho_{c}$ でいずれも定数となる. したがって，橴滞流におい て相対速度分布の平均は零, 分散 $\sigma_{z c}{ }^{2}$ は定数となり次 式で表わされる.

$$
\sigma_{z c}{ }^{2}=2\left(\sigma_{c}{ }^{2}-\operatorname{Cov}_{c}\right)=2 \sigma_{c}^{2}\left(1-\rho_{c}\right)
$$

ここに,

$$
\rho_{c}=\operatorname{Cov}_{c} / \sigma_{c}{ }^{2}
$$

以上の結果から, 非渋滞流, 啮滞流における速度分布 と相対速度分布の関係が明らかになり，また，おのおの のパラメーターが車頭時間の関数として定式化できた.

こうして得られた理論值が 図一2〜図-5 に示す実線で あり，データより求めたものとよく合致しているといえ る.

\section{（3）自由車率・追従車率の定義と誘導}

前節の結果を, 交通流の自由車・追従車構成の観点か ら考察しよう. すなわち, 先行車・後続車の速度の相関 が, 非渋滞流では車頭時間の減少に伴い高くなり, 渋滞 流では常に高い水準で一定であること, 相対速度分布の 分散は非渋滞流では車頭時間の減少に伴い減少し, 渋滞 流では常に小さな值をとり，一定であるとみなし得るこ とから, 相対速度分布が交通流の内部構造を反映してい ると判断できる. そこで, 相対速度分布の分散を指標と して, 自由車・追従車の構成割合を定式化することが妥 当であると考えられる. また, 渋滞流はすべて追従車で 構成され, 非渋滞流のみ交通流の内部構造が変化すると みなすこともできる.

そこで, 非政滞流における相対速度分布の密度関数に ついて次式を仮定する.

$$
\phi_{f}(z)=\alpha \phi_{f f}(z)+(1-\alpha) \phi_{f g}(z)
$$

ここに, $\phi_{f}(z)$ : 相対速度分布の密度関数, $\phi_{f f}(z):$ 全 車自由走行時の相対速度分布の密度関数, $\phi_{f g}(z)$ : 全 車追従走行時の相対速度分布の密度関数, $\alpha: \phi_{f}(z)$ に

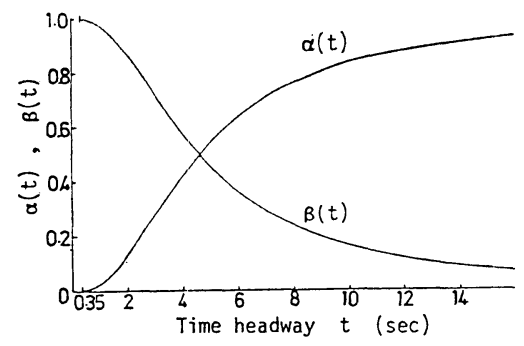

図一6 $a(t), \beta(t)$ と車幁時間との関係
おいて $\phi_{f f}(z)$ の占める割合.

全車自由走行となるのは, $t \rightarrow \infty$ のときであり, 全車 追従走行となるのは， $t=t_{0}$ のときであるから，前節に 定義した $\sigma_{z} f_{\text {max }}^{2}, \sigma_{z} f^{2}$ min ことを考虑し式 (10) より相対速度分布 $\phi_{f}(z)$ の 分散 $\sigma_{z} f^{2}$ を求めれば次式となる.

$$
\sigma_{z f^{2}}=\alpha \sigma_{z f_{\text {max }}^{2}}+(1-\alpha) \sigma_{z f_{\text {min }}}
$$

上式を $\alpha$ について解けば次式が得られる.

$$
\alpha=\frac{\sigma_{z} f^{2}-\sigma_{z} f_{\text {min }}^{2}}{\sigma_{z f^{2} \max }-\sigma_{z f^{2} \min }}
$$

式（12）において, $\sigma_{z} f^{2}$ は車頭時間の関数であり

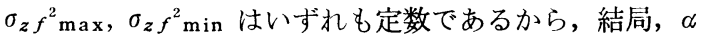
は車頭時間の関数 $\alpha=\alpha(t)$ となり，式 (5)，(6) およ び式（7）を用いて式（13）が得られる.また， $\beta(t)=1$ - $\alpha(t)$ と扩けば式 (14) が得られる.

$$
\begin{aligned}
& \alpha(t)=\frac{A\left(t-t_{0}\right)^{2}}{A\left(t-t_{0}\right)^{2}+1} \\
& \beta(t)=\frac{1}{A\left(t-t_{0}\right)^{2}+1}
\end{aligned}
$$

式 (13)，(14）の誘導過程から明らかなように, $\alpha(t), \beta$ （ $t$ ）は車頭時間 $l$ で走行する車の中での自由車, 追従車 の割合を表わすものと考えられ，その意味で，これらを 自由車率, 追従車率とよぶことにする. $\alpha(t)$ と $\beta(t)$ と 車頭時間との関係を 図一6に示寸.

\section{3. 車頭時間分布モデル}

これまでの考察の結果，非渋滞流は自由車と追従車と から構成され, 車頭時間によりその構成割合が変化し， 渋滞流はすべて追従車で構成されるといえる．したがっ て，渋滞流は非渋滞流の考察成果を踏まえることにより 論ずることができるので，ここでは，非渋滞流における 自由車・追従車構成とその車頭時間分布モデルについて 検討することにする.

先に定義した $\alpha(t), \beta(t)$ を用いて, 非渋滞流におけ る車頭時間分布は, 自由車に関するものと追従車に関す るものとに分けることができる（図一7）。このとき, 全

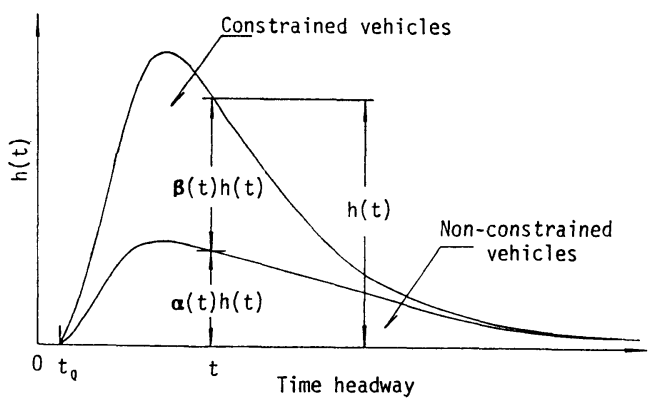

図一7車頭時間分布の構成 
交通流中に自由車・追従車が占める割合を, それぞれ自 由車割合 $P_{f}$, 追従車割合 $P_{g}$ とすると, $P_{f}+P_{g}=1$ であり, 次式で求められる.

$$
\begin{aligned}
& P_{f}=\int_{t_{0}}^{\infty} \alpha(t) h_{f}(t) d t . \\
& P_{g}=\int_{t_{0}}^{\infty} \beta(t) h_{f}(t) d t .
\end{aligned}
$$

ここに, $h_{f}(t)$ : 非渋滞流における 車頭時間分布の密度 関数.

自由車, 追従車の車頭時間分布の密度関数をそれぞれ $f(t), g(t)$ として

$$
\begin{aligned}
& \alpha(t) h_{f}(t)=P_{f} f(t) \\
& \beta(t) h_{f}(t)=P_{g} g(t)
\end{aligned}
$$

なる関係を仮定すれば, $h_{f}(t)$ は

$$
h_{f}(t)=P_{f} f(t)+P_{g} g(t) \quad(モ テ ゙ ル 1)
$$

と表わされる. 上記モデルの場合， $P_{f}, P_{g}$ は $h_{f}(t)$, $f(t), g(t)$ の車頭時間の平均をそれぞれ $T, T_{f}, T_{g}$ と するとき，次式により計算叮能である.

$$
\begin{gathered}
P_{f}=\frac{T-T_{g}}{T_{f}-T_{g}} \\
P_{g}=\frac{T_{f}-T}{T_{f}-T_{g}}
\end{gathered}
$$

ここに，T=3600/Q（s)，Q：交通量 $(\mathrm{VPH})$

他方，式 (17)，(18）をそれぞれ個別に解くことによ り,

$$
\begin{aligned}
& h_{f}(t)=\frac{P_{f}}{\alpha(t)} f(t) \quad(\text { モデル } 2) \\
& h_{f}(t)=\frac{P_{g}}{\beta(t)} g(t) \quad(\text { モデル } 3)
\end{aligned}
$$

を得る.これらのモデルは, $h_{f}(t)$ を $f(t), g(t)$ のい ずれか一方のみで表わし得ることを意味し興味深いが, さらに詳しく検討すると, 式 (22)，(23) はそれぞれ次 のように展開される.

$$
\begin{aligned}
& h_{f}(t)=P_{f} f(t)+P_{f} \frac{\beta(t)}{\alpha(t)} f(t) \\
& h_{f}(t)=P_{g} \frac{\alpha(t)}{\beta(t)} g(t)+P_{g} g(t) \cdots
\end{aligned}
$$

式 (24)，(25）の右辺第 1 項は自由車, 第 2 項は追従車 に関する車頭時間分布を表わしており, 結局, これらの モデルは, 暗黙のうちに次式を仮定したものにほかなら ない.

$$
\begin{aligned}
& f(t)=\frac{P_{g}}{P_{f}} \frac{\alpha(t)}{\beta(t)} g(t) \\
& g(t)=\frac{P_{f}}{P_{g}} \frac{\beta(t)}{\alpha(t)} f(t)
\end{aligned}
$$

また，これらのモデルでは，式 $(22) ，(23)$ の一般形の ままで $P_{f}, P_{g}$ をモデル 1 の場合のように車頭時間の平 均により表現することはできないが，モデル 3 は $\beta(t)$ として, 式 (14) を用いるとき, 式 (23) が

$$
h_{f}(t)=P_{g}\left\{A\left(t-t_{0}\right)^{2}+1\right\} g(t)
$$

$$
=P_{g} A\left(t-t_{0}\right)^{2} g(t)+P_{g} g(t)
$$

となることから, $g(t)$ の平均 $T_{g}$ と分散 $V_{g}$ とを用い, $P_{f}, P_{g}$ を次のように求めることができる.

$$
\begin{aligned}
& P_{f}=\frac{A\left\{V_{g}+\left(T_{g}-t_{0}\right)^{2}\right\}}{A\left\{V_{g}+\left(T_{g}-t_{0}\right)^{2}\right\}+1} \\
& P_{o}=\frac{1}{A\left\{V_{g}+\left(T_{g}-t_{0}\right)^{2}\right\}+1}
\end{aligned}
$$

以上, 式 (17)，(18）を仮定することにより，3 種類 の車頭時間分布モデルが導かれた. これらのうち, モデ ル 1 は右辺が確率密度を表わすことが確かめられ, また $P_{f}, P_{g}$ と分布の統計量との間には整合性が保証され, 本研究の提案とするものである. モデル 2,3 は $\alpha(t)$, $\beta(t)$ の内容によっては, 右辺が確率密度関数を表わす ことを必ずしも保証するものでない. また, 式 (13), (14)の $\alpha(t), \beta(t)$ はデータへの回帰曲線より任意的に 与.えられたものであるから，式（25）をモデルに利用す ることは叮能でも，式 (26)，(27）が成立することを保 証するものではない.これらのことから, 式 (22), (23) のモデルは理論上存在するが, その活用においては問題 が多いことを付言しておく.

\section{4. 観測データによるモデルの評価}

\section{（1） モデルのあてはめ}

観測データを用いて提案モデルを具体的に求めるが, 非渋滞流, 渋滞流における車頭時間分布の密度関数をそ れぞれ $h_{f}(t), h_{c}(t)$ とすれば, $h_{f}(t)$ は自由車, 追従 車の車頭時間分布の密度関数 $f(t), g(t)$ により, $h_{c}(t)$ は追従車のみの単一分布により表現される.そこで, こ れらに対しどのような理論分布を仮定するかが問題とな るが, これまで著者らが種々の理論分布について検討を 行った結果, いずれも対数正規分布を仮定する場合が 最も良好な結果を与えることが判明した．すなわち， $f(t), g(t), h_{c}(t)$ に対して次の対数正規分布を仮定す る.

$$
\begin{aligned}
f(t)= & \frac{1}{\sqrt{2 \pi} \zeta_{f}\left(t-t_{0}\right)} \\
& \cdot \exp \left\{-\frac{1}{2}\left(\frac{\ln \left(t-t_{0}\right)-\xi_{f}}{\zeta_{f}}\right)^{2}\right\}
\end{aligned}
$$

$g(t), h_{c}(t)$ は, 式 (31) においてパラメーター $\xi_{f}, \zeta_{f}$ をそれぞれ $\xi_{g}, \zeta_{g}$ および $\xi_{c}, \zeta_{c}$ に置換したものであ る.

観測データへのあてはめにあたり, 非渋滞流において は車頭時間の観測データを自由車に関するものと, 追従 車に関するものとに分ける必要がある.そこで本研究で は, 車頭時間を 0.3 秒ごとにクラス分けし, 各階級值に 対する $\alpha(t), \beta(t)$ を計算し, これらを各クラスのデー 
タ頻度に乗ずることにより, 自由車, 追従車に関する車 頭時間分布を推定的に求め分離した. そのらえで, これ らをデータとして $f(t), g(t)$ に対する仮定理論分布の あてはめを行い, 各交通量レベルに対する $f(t), g(t)$ を定式化した. また, 自由車, 追従車の車頭時間が分離 された結果, $P_{f}, P_{g}$ は定義から明らかなよらに, 自由 車, 追従車それぞれの総和と全データとの比で求められ る.

一方, 渋滞流は, 非渋滞流の場合と同様なクラス分け を行い, 直接, $h_{c}(t)$ に対する仮定理論分布のあてはめ を行えばよい.

以上の考え方により，まず $f(t), g(t), h_{c}(t)$ に基ゔ く車頭時間の平均と分散を求め, これらと交通量との関 係を定式化する. 次いで，その結果を用い分布のパラメ ーターと交通量との関係を定式化し，さらに得られたパ ラメーターを用いた計算值と観測データとを比較し，そ の適合度を検討するものである。

\section{（2）車頭時間分布の平均・分散と交通量との関係}

非渋滞流, 䠖滞流のデータより各交通量レベルにおう る車頭時間の平均・分散を推定し, 交通量（1 分閒交通

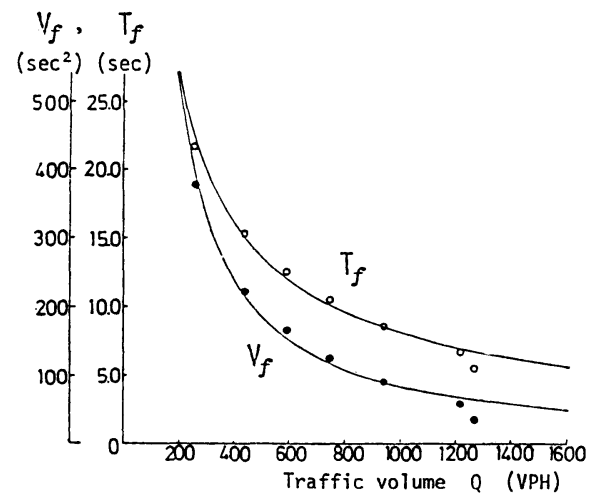

(a) Non-congested flow: non-constrained vehicles

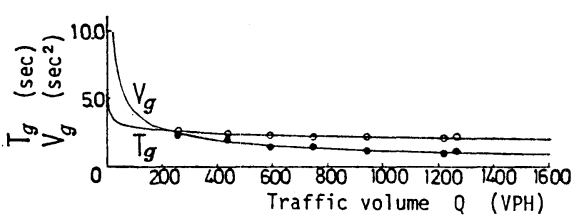

(b) Non-constrained flow : constrained vehicles

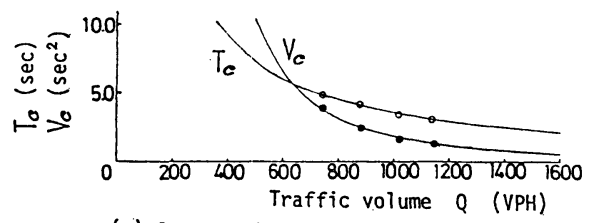

(c) Congested flow

図一8 車頭時間分布の平均・分散と交通年との関係
量を時間交通量に換算したもので定義する）との関係と して, $n$ 次曲線を仮定のうえ回帰演算を行った結果次の 諸式を得た. データと回帰曲線との対比を 図一8に示 す.

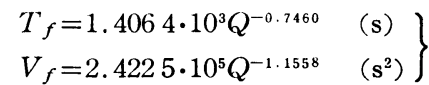

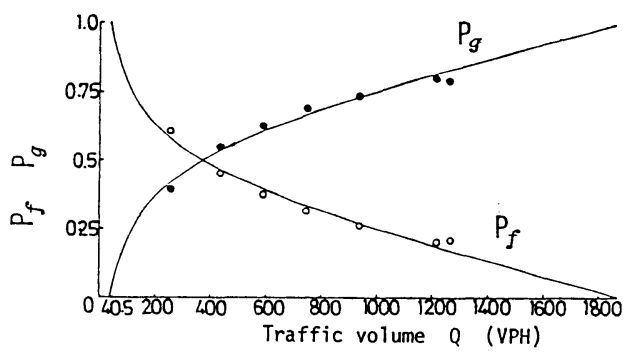

図一9 $P_{f}, P_{g}$ と交通韋との関係

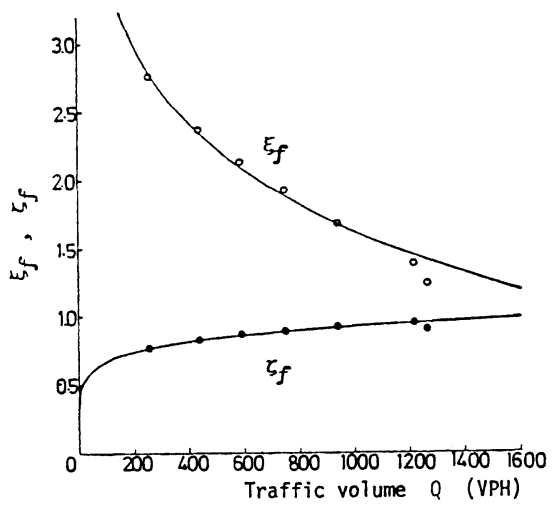

(a) Non-congested flow: $f(t)$

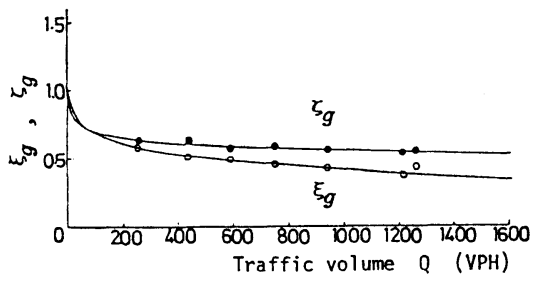

(b) Non-congested flow : $g(t)$

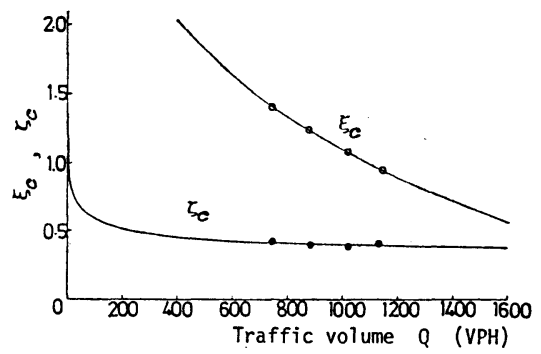

(c) Congested flow: $h_{e}(t)$

図一10 車頭時間分布モデルのパラメーターと 交通早との閶保 


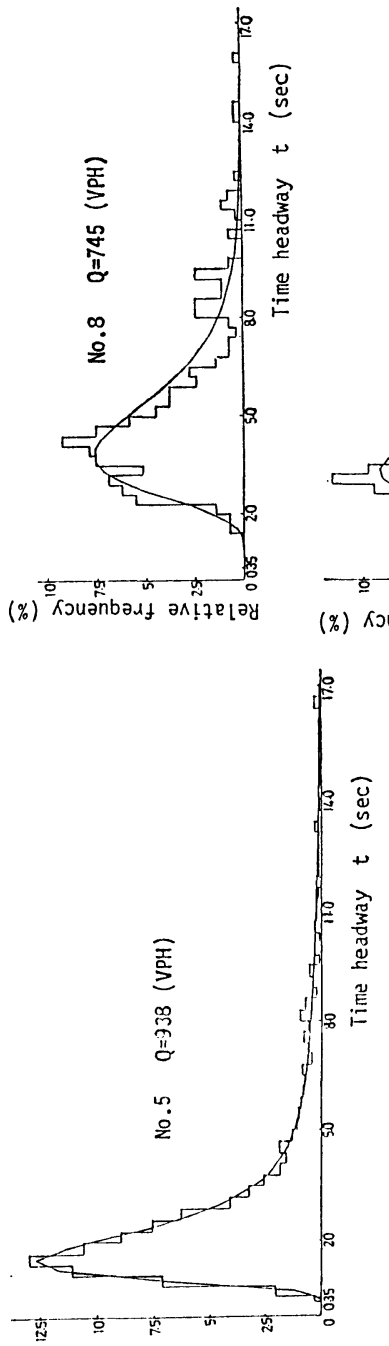

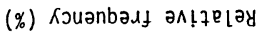

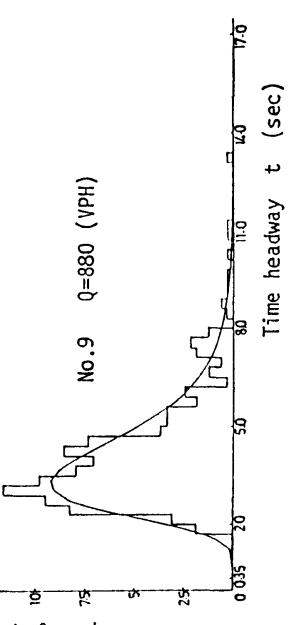

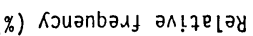

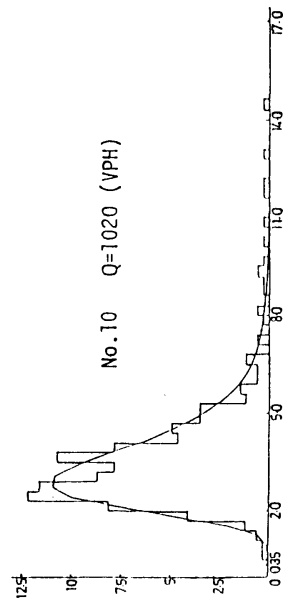

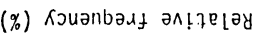

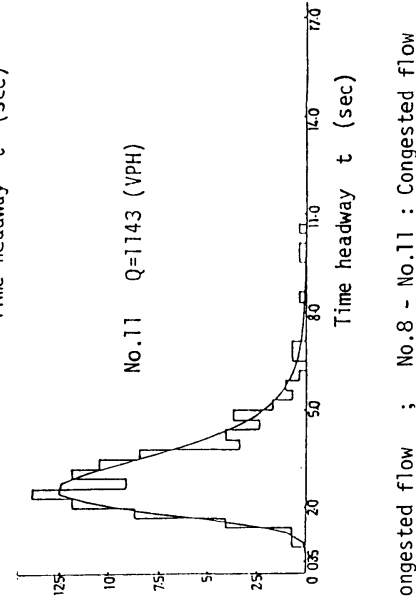

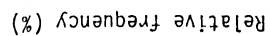

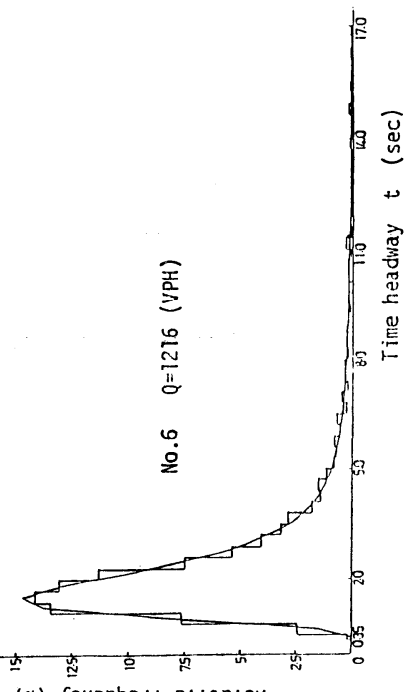

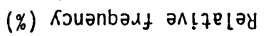

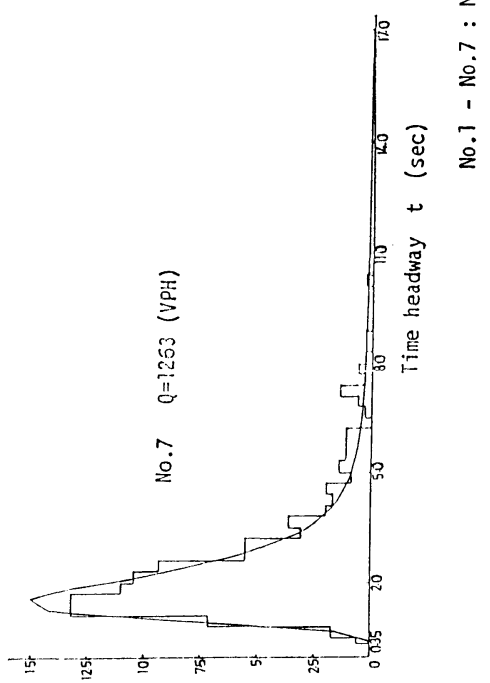

(\%) Kouanbart å!7elay

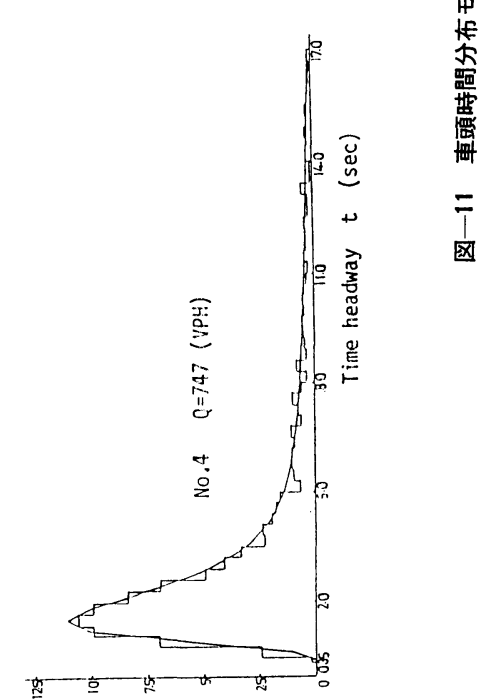

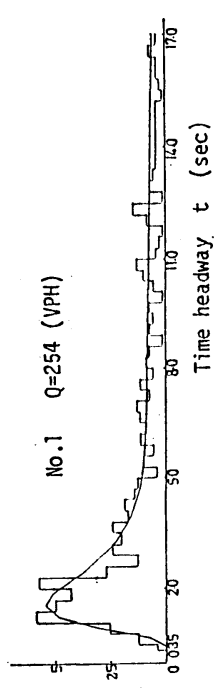

(\%) Kכuәnbəגf

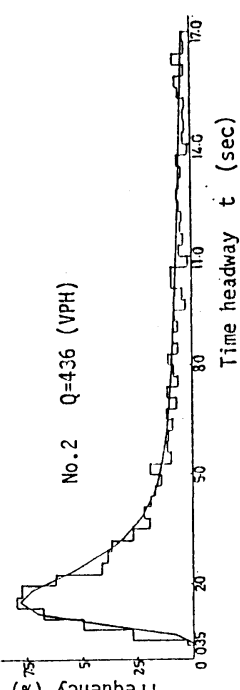

(\%) Kouənbəut

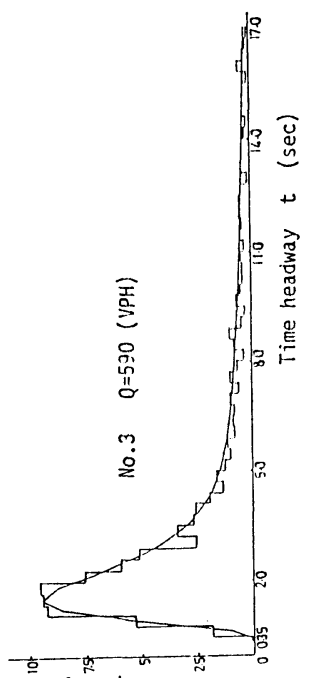

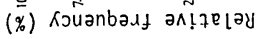

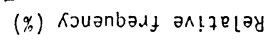

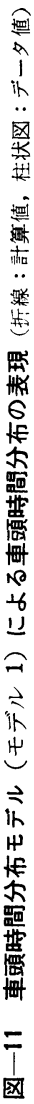

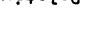



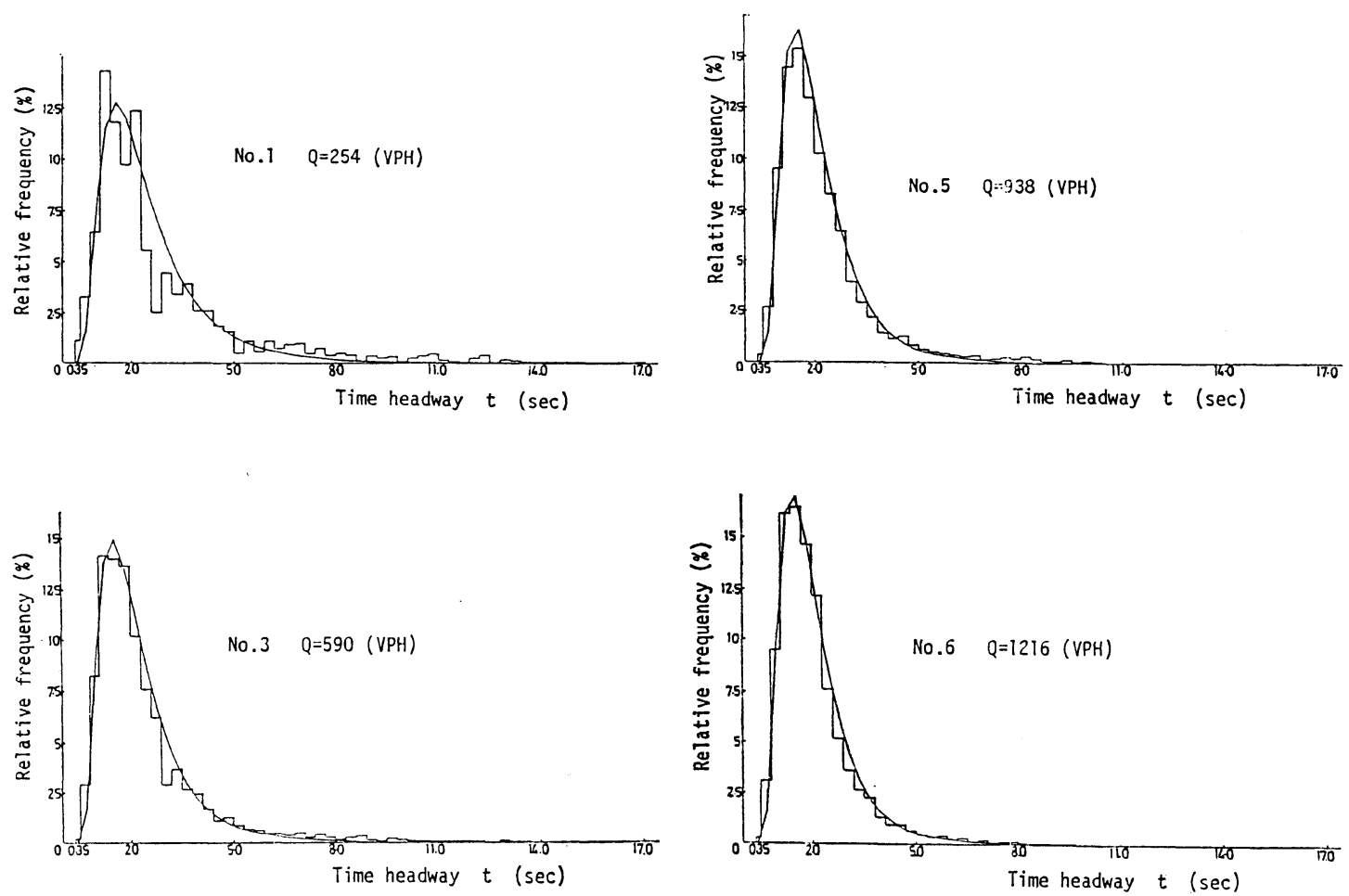

(a) Non-congested flow : Constrained vehicles
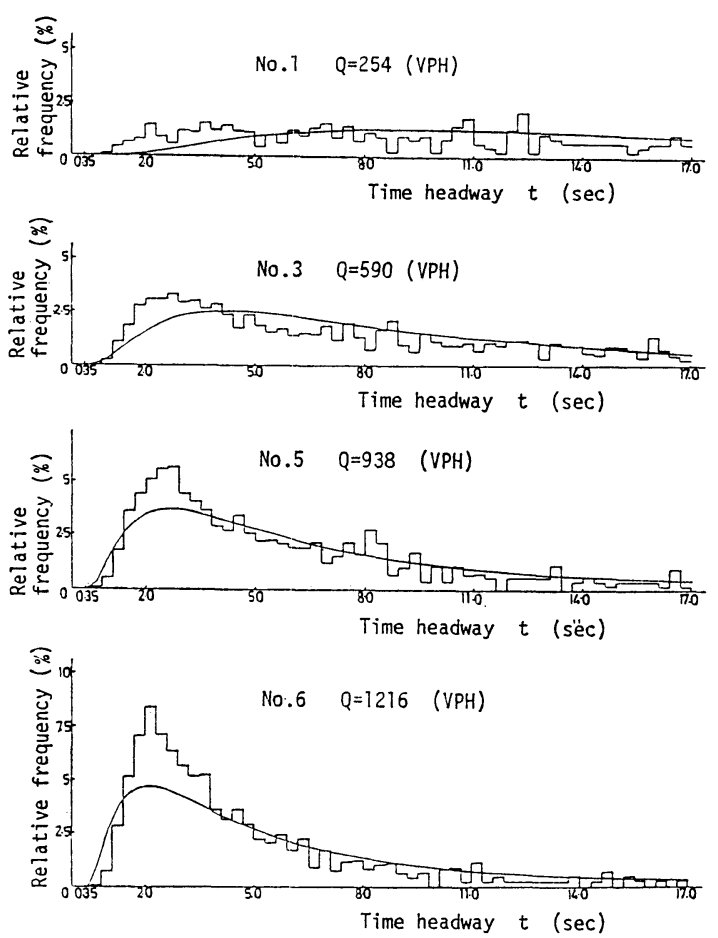

(b) Non-congested flow : non-constrained vehicles

図一12 車頭時間分布モデルによる $f(t), g(t)$ の表現 （折線：計算値, 柱状図: デー夕値）

$$
\left.\begin{array}{ll}
T_{g}=5.4035 Q^{-0.1366} & (\mathrm{~s}) \\
V_{g}=5.3511 \cdot 10 Q^{-0.5614} & \left(\mathrm{~s}^{2}\right)
\end{array}\right\}
$$

ここに, $Q:$ 交通量 (VPH)

またデータを分離することにより得られた $P_{f}, P_{g}$ の 值と, 式 (32)，(33) の $T_{f}, T_{g}$ を式 (20)，(21) に代 入して得られる計算值との比較を図一9に示す. データ 值と計算值とはよく一致しているが, 計算值は, 交通量 $40 \mathrm{VPH}$ 以下のところで $P_{f}$ が 1 より大となり, 1850 $\mathrm{VPH}$ 以上で負となり, この点不合理である.しかし， $P_{f}$ が 1 以上となる部分に対しては $P_{f}=1, P_{f}$ が負と なる部分に対しては $P_{f}=0$ とおけば，提案モデルの実 用上の意義は何ら損なわれるものではない.すなわち， 交通量 $40 \mathrm{VPH}$ 以下では理論的に全車自由車とみなす もので，1850 VPH は本観測で対象とした道路・交通 条件下における最大交通量（可能交通容量相当値）であ ると理解できる.

\section{（3）パラメーターと交通量との関係}

車頭時間分布モデルとして, 式 (31) を仮定するとき, モデルのパラメーターと分布の平均・分散との間には

$$
\xi_{f}=\ln \left(T_{f}-t_{0}\right)-\frac{1}{2} \ln \left\{\frac{V_{f}}{\left(T_{f}-t_{0}\right)^{2}}+1\right\}
$$


表-2 車頭時間分布モデルの $\chi^{2}$ 適合度検定

\begin{tabular}{c|c|c|c|c}
\hline Data No. & \multicolumn{1}{|c|}{$Q$} & d.f. & Chi Square & Good Fit \\
\hline 1 & 254 & 10 & 11.39 & Yes \\
2 & 436 & 12 & 19.32 & Yes \\
3 & 590 & 13 & 21.51 & Yes \\
4 & 747 & 14 & 17.67 & Yes \\
5 & 938 & 12 & 13.71 & Yes \\
6 & 1216 & 11 & 10.34 & Yes \\
7 & 1263 & 9 & 14.24 & Yes \\
8 & 745 & 7 & 8.96 & Yes \\
9 & 880 & 7 & 6.92 & Yes \\
10 & 1020 & 8 & 4.89 & Yes \\
11 & 1143 & 8 & 3.34 & Yes \\
\hline
\end{tabular}

No. $1 \sim$ No. 7 : Non congested flow

No. 8 No. 11 : Congested flow

$Q$ : Traffic volume (VPH), d.f. : Degree of freedom

Significance level $=5 \%$

$$
\zeta_{f}=\sqrt{\ln \left\{\begin{array}{c}
V_{f} \\
\left(T_{f}-t_{0}\right)^{2}
\end{array}+1\right\}}
$$

0)関係がある。 $\xi_{g} ， \zeta g$ および $\xi_{c} ， \zeta c$ は式 (35)，(36) で $T_{f}, V_{f}$ をそれぞれ $T_{g}, V_{g}$ および $T_{c}, V_{c}$ と置換 したものである.上式に式（32）（34）をそれぞれ代人 することにより, パラメーターと交通量との関係が求め られるが，その結果を 図一10 に示す. 計算值はデータ とよく一致している.

\section{（4）モデルの適合度検定}

$f(t), g(t), h_{c}(t)$ の理論分布うして , 対数正規分布 $\mathrm{j}$ 仮定した場合の各パラメーターと交通量との関係が定式 化されたので, 非渋滞時, 渋滞時の車頭時間分布は交通 量を与えるのみで計算可能になる。図一11 は観測 デー 夕に対応する交通量により計算されたパラメーターを用 いて得られたモデル $h_{f}(t), h_{c}(t)$ と観測データの分布 との比較を示す. また表一2にモデルの観測データに対 する適合度を $\chi^{2}$ 検定した結果を示す。

これらの結果から, 提案モデルは，1秒以下の車頭時 間の頻度をやや過小評価する傾向はあるものの，いずれ の交通量状態に対しても現実のデータを十分良好に表現 していることがわかる. また， $f(t), g(t)$ に対するデー タともデルとの比較の一例を 図一12 に示すが, いずれ もモデルは妥当な表現を与えているといえる.

\section{5.むすび}

本研究は, 郊外 2 申線追越禁止間におりる非渋滞 流, 渋滞流を対象とし, 連行する 2 台の車の速度の相関 と車頭時間との関係に基づいて交通流を構成する車を自 由車, 追従車に分離することにより, 自由車, 追従車構 成の観点から交通流の内部構造を明らかにすること, お よび，車頭時間分布を自由車，追従車のそれに基ついて 記述し定式化することを提案した. その過程で得られた
事項を要約すると以下のとおりである.

（1）連行する 2 台の車の速度の相関は，渋滞流では 車頭時間に関係せず高い水準で一定であり, 非渋帯流で は車頭時間が小さくなるほど高くなり, 渋滞流の水準に 近づく.このことから, 渋滞流は追従車のみから, 非啮 滞流は自由車, 追従車とから構成されるとみなし得る.

（2）非渋滞流における自由車, 追従車構成の変化 は，相対速度分布の変化に反映されるとみなすことがで き, 車頭時間分布は，相対速度分布の分散を指標として 導かれる 自由車率 $\alpha(t)$ ，あるいは追従車率 $\beta(t)$ によ り, 自由車に関するものと追従車に関するものとに分離 叮能であり, 車頭時間分布からみた自由車・追従車とい ら交通流の内部構造を明らかにすることができる.

（3）郊外 2 車線追越禁止风閒の交通流における車䫓 時䦎分布は，非泚滞流は自由車・追従車のいずれにも対 数正規分布を仮定した複合分布モデルを，追従東のみの 啮滞流は単一奶数正規分布モデルを適肘寸ることにより 良好に表現される。

（4）各分布モデルのパラメーターは，各分布けハ:ラ メーターと交通量との関係を定式化した結果を朋いるこ とにより，交通量との関係が走式化され，各交通量レ心゙

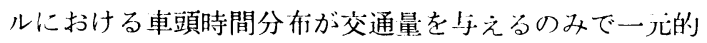
に表現される。

なお，本研究は一般国道 2 車線追越禁止区間を対象と して定式化されたものであるが, 追越しの許される 2 車 線道路でも, 交通量の増加に伴い実際上, 追越しはほと んど不川能となることから，ここで得られた内容はその ままこれらの区間に対しても適用可能であると推察され る. また, 本研究で提案した自由車, 追従車の分離に基 うく一連の交通流分析方法は, 多車線道路, 高速道路の 交通流の分析に対しても有効であると考えられ，今後の 研究課題としたい.

謝辞：本研究の遂行にあたり，多大な励ましとご 援助を賜わった山口大学建設工学科 留田忠義教授に哚 甚な謝意を表します.

\section{考卖 献}

1) Greenberg, I. : The log-normal distribution of headways, Austral. Road Res., Vol. 2, pp. 14 18, 1966.

2) Tolle, J.E. : The lognormal headway distribution model, Traffic Engineering +Control, Vol. 13, pp. 22 $\sim 24,1971$.

3) Schuhl, A. : The probability theory applied to distribution of vehicles on two lane highway, Poisson and traffic, Eno foundations, pp. 59 75, 1955.

4) Buckley, D.J. : Road traffic headway distributions, Proc. Austral. Road Res. Bd., Vol. 1, pp. 153 187, 1962.

5）高田 弘：電子計算機を利用したシミュレーションによ る道路交通流り解析，上木学全棆文報售集，No. 124， 
pp. 28 40, 1965 .

6) Buckley, D.J. : A semi-poisson model of traffic flow, Transpn. Sci., Vol. 3, pp. 107 133, 1968.

7) Katakura, M. : Time headway distribution of traffic flow, Proc. of JSCE., No. 189, pp. 107 115, 1971.

8) Tolle, J.E. : Vehicular headway distribution : testing and results, Transpn. Res. Rec., No. 456, pp. 56 64, 1976.

9) Wasielewski, P. : Car-following headways on freeways interpreted by the semi-poisson headway distribution model, Transpn. Sci., Vol. 13, pp. 36 55, 1979.

10) Miller, A.J. : A queueing model for road traffic flow, J. Roy. Statist. Soc. Ser. B, Vol. 23, pp. $64 \sim 75$,
1961.

11) Underwood, R.T. : Traffic flow and bunching, J. Austral. Road Res., Vol. 2, pp. 8 25, 1963.

12) Daou, A. : On flow within platoons, Austral. Road Res., Vol. 2, pp. 4 13, 1966.

13) Taylor, M.P.A. et al. : A comparison of some bunching models for rural traffic flow, Transpn. Res., Vol. 8, pp. 1 9, 1974.

14）田村洋一・㯪木 武 : 䠈滞・非渋滞時 交通現象につい て, 第 34 回土木学会中国四国支部年次学術講演概要集, pp. 248 249, 1982.

(1982.9.6 - 受付) 